\title{
A partisan model of government expenditure
}

\author{
THOMAS BRÄUNINGER \\ Department of Politics and Management \& Center for Junior Research Fellows, University of Konstanz \\ Universitätsstr. 10, 78457 Konstanz, Germany; E-mail: thomas.braeuninger@uni-konstanz.de
}

\begin{abstract}
Partisan models of budget politics largely concentrate on the size of government, budget deficits and debt, but most theories have little to say as to what the effect of party politics on both the size and the composition of budgets is. This paper seeks to extend previous literature in two directions. First, a model of spending preferences is developed that relates actors' preferred level and allocation of expenditure to electoral gains from fiscal policies. Second, changes in both total expenditure and the expenditure mix of two budget categories are analyzed for the effect of parties' spending preferences as stated in their election manifestos. Using data on 19 OECD countries from 1971 to 1999, the paper finds support for general partisan hypothesis. The results suggest that the actual spending preferences of parties matter whereas they do not indicate that parties of the left consistently differ from parties of the right in their spending behavior.
\end{abstract}

\section{Introduction ${ }^{1}$}

The role of party politics in framing budgetary policy-making is a carefully explored issue in the literature. In a nutshell, the partisan politics model states that left- and right-leaning parties differ not only in their macro-economic policies and fiscal outcomes, notably the trade-off between inflation and unemployment but also the level of public expenditure and the size of budget deficits (e.g., Hibbs, 1977, 1987; Tufte, 1978). According to the basic hypothesis, parties competing for votes promise to implement programs that best serve the groups they represent. As lower income groups are generally in favor of a large, active and market-regulating state and tend to be more attached to parties on the left, socialist or social democratic parties are postulated to generate lower unemployment but higher levels of public expenditure and budget deficits.

Findings on the partisan sources of fiscal outcomes, however, are mixed. In a review of the empirical literature, Cusack (1997: 378) lists studies that dismiss the expected dependence of public spending on party preferences (Rose, 1984), studies that report a possible but modest impact (von Beyme, 1985; Blais, Blake, \& Dion, 1993) as well as studies suggesting strong causal relationships (Comiskey, 1993; Roubini \& Sachs, 1989). One conclusion is that parties do not significantly differ in their macroeconomic policies and even if they did so in the past, international financial integration eliminates 
distinct partisan differences (Garrett \& Lange, 1991). Recent studies point to the intertwined effects of party politics and political institutions arguing that partisan distinctions are evident in countries with fixed exchange rate regimes (Oatley, 1999: 1005) or when organized labor is strong (Garrett, 1998: 11).

But even if the left-right ideological position of parties turns out to be (or have become) irrelevant, there is no reason to dismiss the notion of partisan politics from the wider theory of public finance. Parties may simply differ in their fiscal priorities or preferences in a way that is unrelated to, or, at least, does not fully coincide with, the seminal dichotomy of left versus right (Hibbs, 1977), the left-center-right trichotomy (Blais et al., 1993), or even a fourfold classification of parties (Schmidt, 1996). The question then becomes whether the partisan composition of governments plays a role in fiscal outcomes because of differences in the preferences of parties rather than differences in their ideological identity. In this paper, I seek to go beyond the standard line of reasoning by emphasizing this distinction between the partisan identity of governmental actors and their policy preferences. Naturally, one would expect programmatic preferences of actors to be related to their partisan identity but the point here is whether the programmatic preferences of government parties are (or remain) pertinent even if the partisan identity proves (or has become) irrelevant for the macroeconomic policies they pursue.

To explore this question the paper proceeds in two steps. I first develop a model of budget politics that is based on the preferences of partisan policymakers with respect to the size of government expenditure and its allocation to functional budget categories: I assume that for electoral reasons partisan actors generally prefer more spending to less but also experience electoral costs from higher expenditure due to the increasing tax burden. Actors differ in terms of the weight they put on "government efficiency" or small budgets as well as the (electoral) salience of spending for different policy areas. I show that actors consequently differ in their preferred budgets, i.e. both the level and the distribution of expenditure. Assuming a top-down budget process in which governmental parties are veto players (Tsebelis, 2002), or, alternatively, the median legislator has the final say, the potential for fiscal policy change is estimated. The hypothesis with respect to the size of total expenditure is that a large potential for policy change to increase spending leads to higher expenditure and vice versa. As to the distribution of government expenditure, the model predicts that a large potential for expenditure change in the direction of a specific policy area results in a reallocation of resources to that area.

In a second step, the two hypotheses are tested using data on parties' programmatic preferences from party manifestos. I analyze the size of government expenditure and its distribution to two key budget categories, social security and economic affairs, using data on 19 OECD countries in the time period 1971-1999. I ask whether the level of government expenditure and its 
allocation to budget categories can be traced back to spending preferences of governmental parties rather than their ideological identity. ${ }^{2}$ The empirical investigation suggests that the distinction between two aspects of partisan politics, the ideological identity of actors and their partisan-based preferences, is worthwhile: the partisan composition of governments is related to their macroeconomic policies; but it is the stated programmatic preferences of parties, not their left or right-wing affiliation that tells us most about their fiscal policies.

The paper is organized as follows. The next section presents a salience model of spending preferences, which is subsequently used to predict changes in fiscal policies. The third section describes the data, particularly the measurement of parties' spending preferences using data from election manifestos. The fourth section discusses the results of the time-series cross-country regression analysis. The fifth section concludes.

\section{Model}

\subsection{A salience model of spending preferences}

In the model, there is a set $N$ of political actors $i=1, \ldots, n$, and a number of spending areas $j=1, \ldots, m$. Spending $x_{j}\left(x_{j}>0\right)$ for any of the $m$ areas sums up to total government expenditure. At this stage, I make no assumptions regarding the nature of these political actors, whether they are political parties (as unitary actors) or individual portfolio ministers with responsibility for the above areas. For the empirical analysis, I will assume that in parliamentary systems governmental parties or the median legislator are veto players, but for now we might also think of actors as individual ministers. Actor $i$ 's utility over a bundle of expenditures may be written as:

$$
u_{i}=\left(1-\lambda_{i}\right) \sum_{j=1}^{m} \alpha_{i j} \ln x_{j}-\lambda_{i} m_{i} T .
$$

It consists of two components. Firstly, actors have Cobb-Douglas type utility functions over expenditure. Utility is monotonically increasing in any $x_{j}$ as political actors simply benefit from larger spending (Niskanen, 1971). The weight $\alpha_{j}$ associated to $x_{j}$ is the salience the actor attributes to this particular spending area or his interest in $j$ (cp. Coleman, 1990: 674). The higher the salience, the larger the electoral rewards for a unit expenditure increase in that area. For simplicity, let $\alpha_{j}>0$ and $\Sigma \alpha_{j}=1$. Secondly, actors consider electoral losses due to the tax burden. Let $T$ be the total tax burden and $m_{i}$ be the share of the tax burden that the constituency of actor $i$ must bear $\left(0 \leq m_{i} \leq 1\right)$ (Hallerberg \& von Hagen, 1999). For simplicity, I assume that the losses are linear in $T .^{3}$ Finally, actors weigh up gains and losses from 
expenditure by a parameter $\lambda_{i}$ which again might (and should) differ between actors. I call $\lambda_{i}$ the tax weight and assume that $\lambda_{i} \in(0,1)$.

To derive the preferred level and allocation of government expenditure I assume that there is a zero deficit budget constraint, i.e. all expenditure in time $t$ has to be raised by tax revenue at time $t$, or $T=\Sigma x_{j}$. Then, by equating the first partial derivates

$$
\frac{\partial u_{i}}{\partial x_{j}}=\left(1-\lambda_{i}\right) \alpha_{j} \frac{1}{x_{j}}-\lambda_{i} m_{i}
$$

to zero gives the ideal point $\hat{x}_{i}=\left(\hat{x}_{i 1}, \ldots, \hat{x}_{i n}\right)$ in the expenditure space:

$$
\hat{x}_{i}=\left(\frac{\left(1-\lambda_{i}\right) \alpha_{1}}{\lambda_{i} m_{i}}, \ldots, \frac{\left(1-\lambda_{i}\right) \alpha_{m}}{\lambda_{i} m_{i}}\right) \text {. }
$$

The preferred total expenditure then becomes $\hat{x}_{i}^{s}=\frac{1-\lambda_{i}}{\lambda_{i} m_{i}}$ and the fact that $\frac{\partial \hat{x}_{i}^{s}}{\partial \lambda_{i}}=-\frac{1}{\lambda_{i}^{2} m_{i}}<0$ establishes the first result.

Proposition 1. The larger the tax weight $\lambda_{i}$, the smaller is the preferred total expenditure. Moreover, the preferred total expenditure level is independent of the saliencies of the spending areas.

I now look at the allocation of the preferred total expenditure to spending areas. Consider a spending area $j$, then the preferred spending share for area $j$ at the ideal spending level is $\frac{\hat{x}_{i j}}{\hat{x}_{i}^{s}}=\alpha_{i j}$. As $\frac{\partial\left(\hat{x}_{i j} / \hat{x}_{i}^{s}\right)}{\partial \alpha_{i j}}=1>0$, a second useful observation is:

Proposition 2. The higher the salience for spending area $j$, the higher the preferred spending share for area $j$. Moreover, the preferred spending mix is independent of the tax weight.

To sum up, the utility functions induce ideal points of preferred spending in the multidimensional expenditure space and actors may differ with respect to both the relative expenditure for spending areas and the preferred total expenditure. The tax weight and the relative salience for a particular area can be used as indicators of the preferred total expenditure and the preferred expenditure share for that area.

\subsection{Fiscal policy change in a top-down budget process}

Now assume that spending decisions can be represented in a standard topdown budget procedure: actors first decide on the size of the budget and subsequent decisions determine the allocation of the total expenditure to spending 
categories. In terms of the above notations let $B=x_{1}+\cdots+x_{m}$ denote total expenditure and $k_{1}=x_{1} / B, \ldots, k_{m-1}=x_{m-1} / B$ represent then the expenditure mix. Voters serially choose $B, k_{1}, \ldots k_{m-1}$. Then the following holds (for proof, see Appendix):

Proposition 3. The spending preferences are separable across $B, k_{1}, \ldots$, $k_{m-1}$, i.e. the expected outcome of voting on one issue has no influence on ideal points on other issues.

Proposition 3 establishes that voter expectations do not play a role in the top-down budget process and the outcomes of all orderings of $B$ to $k_{m-1}$ on the agenda are identical and as if each issue is voted on separately. This stands in contrast to the standard spatial voting model in which actors have "Euclidean preferences" (circular indifference contours) which are separable across spending dimensions $x_{1}, \ldots, x_{m}$ but not across $B, k_{1}, \ldots, k_{m-1}$ (Enelow \& Hinich, 1984: 141-155; see also Denzau \& Mackay, 1981). Given Proposition 3, fiscal policy change in a top-down budget process can be determined by looking at the issues $B$ to $k_{m-1}$ one by one. As to decision making in the budget process I consider two simple variants:

Median legislator model. According to the standard legislative model with completely competitive voting under simple majority rule, the median legislator in parliament has the pivot vote and determines the outcome (e.g., Enelow \& Hinich, 1984; Kraan, 1996). The issue-by-issue median will be the unique outcome and the expected policy change between subsequent years is given by the change in the median position on every issue $z \in\left\{B, k_{1}, \ldots, k_{m-1}\right\}$ :

$$
P C_{t}^{\mathrm{med}}(z)=z_{t}^{\mathrm{med}}-z_{t-1}^{\mathrm{med}}
$$

This is certainly an institution-sparse view that may overestimate the potential for fiscal policy change if, for instance, actual spending decisions are vested in the government but each member of a coalition government is a potential veto player and large differences in their spending preferences make changes unattainable.

Veto player model. To capture the above effect, I use a variation of Tsebelis (2002) veto player model. Suppose that all governmental parties have a veto over fiscal policy change so that the winset, i.e. the set of alternatives on which all veto actors can agree on, defines the potential for changing the status quo. Veto player theory has nothing to say on what the final choice is but assuming that governmental veto actors chose only Pareto optimal policies, the status quo at time $t$ will likely be located somewhere in the Pareto set of the predecessor government at time $t-1, P S_{t-1}$. Consequently, I use half the size of the winset, averaged over all likely status quo locations, to approximate 
the expected fiscal policy change on any issue $z \in\left\{B, k_{1}, \ldots, k_{m-1}\right\}$ :

$$
P C_{t}^{\mathrm{veto}}(z)=\int_{y \in P S_{t-1}(z)}\left(\arg \min _{s \in P S_{t}(z)}\{\|y-s\|\}-y\right) d y
$$

For both the median and the veto player model, the hypothesis with respect to the size of total expenditure is that a large potential for fiscal policy change to increase spending leads to higher expenditure and vice versa. As to the expenditure mix, the model predicts that a large potential for fiscal policy change in the direction of a specific policy area results in a reallocation of resources to that area.

\section{Data}

The database of this analysis includes 19 OECD countries and covers the time period 1971-1999. The countries are Australia, Austria, Belgium, Canada, Denmark, Finland, France, Germany, Iceland, Ireland, Italy, Luxembourg, Netherlands, New Zealand, Norway, Portugal, Spain, Sweden, and United Kingdom. In this section, I describe the measurement of the fiscal and political variables used in the analysis of changes in the size and structure of governmental outlays.

Central government expenditure data is taken from the IMF's Government Finance Statistics. The data covers all expenditures for consolidated central government including budgetary, social security, and extrabudgetary accounts. Figures exclude transactions between units of central government to avoid double counting but take account of transfers from, or to, other state or regional levels of government. Even though IMF outlay data can be consistently classified along eight specific budget categories, the empirical test of the expenditure mix hypothesis focuses on the two second largest budget items, 'Social Security and Welfare' and on 'Economic Affairs and Services', ${ }^{4}$ for two reasons. Firstly, although expenditure for 'General Public Service' makes up the largest spending item, it comprises a range of areas such as executive organs, external affairs, and public order and safety. This makes it difficult to find a reliable measure for the salience a party attaches to these issues. Secondly, some spending items such as 'Recreation and Culture' are small and seemingly unimportant so that measuring party salience faces a similar problem. Several countries have refrained from reporting their financial accounts in the IMF way for a number of years so that about $80 \%$ of valid data in the time period is available.

As to the impact of partisan politics on public policy and finance, the question of how to measure differences in the policy positions of parties and voters has recently re-attracted extensive attention in the literature (cp. Budge, 2001). In the past, party family categorization has been employed to analyze 
the implications of nominal partisan labels rather than preferences on economic policies (Hibbs, 1977; see also Garrett, 1998: 162, Fn. 8). Expert surveys (e.g. Castles \& Mair, 1984) have frequently been used to locate parties on an ideological-programmatic left-right scale and to analyze their impact on fiscal outcomes (Cusack, 1997; Volkerink \& de Haan, 2001; Franzese, 2002). Expert judgements, however, are less sensitive to positional changes over time and party differences regarding a large number of policy issues. Moreover, it is well-known that even simple party rankings change when switching from one policy area to another (Laver \& Hunt, 1992). Crucially, the retrospective judgement raises questions as to the relation of ex ante preferences and observed behavior. ${ }^{5}$

Explaining changes in the composition of budgets may require a timespecific measurement of policy positions with respect to distinct budget categories. In this paper I make use of data on party policy positions that is derived from party programmes through thematic content analysis. This data, collected by the Comparative Manifesto Project (CMP), provides information on policy emphasis of nearly all effective parties in OECD countries on a wide range of issue areas (Budge, Robertson, \& Hearl, 1987; Budge et al., 2001; Laver \& Budge, 1992). As party preferences are measured for each election period, published party manifesto documents provide time- and context-specific information. While it might be argued that manifestos are strategically written texts, it is evident that published party documents, to a certain extent, bind parties whose electoral success depends on their credibility. Given this, I use party manifesto data as the best available information on the true policy positions of political actors that allows for the analysis of cross-sectional differences and trends over time.

The CMP dataset reports the total number of (quasi-)sentences in a party manifesto that put policy emphasis on a specific issue area. CMP data is perfectly suitable for the present study as its coding scheme is based on salience theory and is not concerned with policy positions but policy emphasis (Laver $\&$ Garry, 2000: 620). From the total of 54 issue areas or categories, I use 15 that were selected along two criteria: First, there is one category, "government and administrative efficiency", that refers to the "need for efficiency and economy in government and administration". I use the number of mentions in the party programme divided by the total number of (quasi-)sentences as a measure for the "tax weight" of a party but admit that this is only a rough measure for the variable in question. Second, all expenditure-relevant CMP categories were selected that refer to either social security and welfare, or economic affairs spending (six and eight categories). ${ }^{6}$ The relative number of statements for social security and welfare issues, for instance, is then used to measure the salience the party attaches to this spending area.

Finally, data on the party composition of parliaments and governments is taken from Budge et al. (2001), Müller and Strøm (2000), and Woldendorp, 
Keman, and Budge (2000). Combining these with the CMP data on the policy area saliencies of governmental parties, the potential for policy change is calculated for all country-years under study.

\section{Empirical Evaluation of the Model}

I expect that changes in the policy preferences of budgetary decision-makers are reflected in changes in the budget composition. Following the above argument, the basic hypothesis to be tested in the following paragraphs is that a change in the size and allocation of expenditure is connected to the size of the potential fiscal policy change between subsequent budgetary years (for summary statistics, see Table A1 in the appendix). The basic specification of the estimated equation has the following form

$$
\begin{aligned}
\Delta X_{t}= & \mathbf{C}^{\prime} \mathbf{B}_{0}+\beta_{1} P O L_{t}+\beta_{2} \Delta Y_{t}+\beta_{3} \Delta U E_{t}+\beta_{4} \Delta D R B_{t} \\
& +\beta_{5} \Delta P O P 65_{t}+\beta_{5} P O P 65_{t-1}+\varepsilon_{t}
\end{aligned}
$$

where the dependent variable $(\Delta X)$ is either the change in total government expenditure (as a fraction of GDP) or the ratio of social security expenditure to the aggregate expenditure on social security and economic affairs. The matrix $\mathbf{C}$ stands for a number of variables that control for the time-series cross-sectional nature of the data. They will be determined later on. The key variable of interest is the political variable $P O L$ (or a set of such variables) which, as I expect, will add to an economic-conditions base model. $P O L$ is the expected policy change in the median and the veto player model, respectively. To compare the results to previous studies, I also test for the impact of the left-right complexion of government (partisan identity model) and the number of government parties (legislative fragmentation model).

The base model is similar to those used by various studies (Roubini \& Sachs, 1989a, b; Kontopoulus \& Perotti, 1999; Volkerink \& de Haan, 2001) and should thus allow for a direct comparison with existing results. Three socio-economic indicators are used to control for non-discretionary changes in total expenditure: the real growth rate $(\Delta Y)$, the change in actual debt servicing costs $(\triangle D R B)$, and the change in the rate of unemployment $(\triangle U E){ }^{7}$ For the analysis of the share of social security expenditure, the change in and the lagged level of the portion of population over $65\left(\triangle P O P 65, P O P 65_{t-1}\right)$ is also included. I regard these factors as being (at first) exogenous to the programmatic positioning of governmental parties as observed in the electoral platforms of parties. Data on unemployment and population data is calculated from OECD Health Data and OECD Labour Force Statistics. Data on economic growth is taken from the United Nation's World Development Indicators dataset. 


\subsection{Impact of party preferences on level of expenditure}

Table 1 shows the results of the economic condition base model and four alternative political-economic models of government expenditure. Throughout the table, the dependent variable is the first difference in the ratio of central government expenditure to GDP. The following time-series cross-section controls are used: first, the full set of country indicators. The restriction that country dummies were equal could be rejected at standard significance levels $(p<.0001)$. As differences between countries with respect to their exogenously determined spending inertia or activity are not of substantive interest in the present context, I do not report coefficients for country indicators. Second, as budget adjustments are likely to show inertia, the lagged level of the dependent variable is included to mitigate the effect that is due to budget changes in the previous year. Including additional lags of levels or differences of the dependent variable is not imperative for theoretical reasons nor does the data suggest so. All standard errors reported are panel corrected according to Beck and Katz (1995).

The base model in Table 1 indicates two things. First, the statistical model performs considerably well. A considerable amount of variation in the data can be explained by socio-economic conditions or is captured by country indicators. Second, the economic controls have the expected sign and all are statistically significant. A rise in unemployment leads to increases in expenditure whereas real-GDP growth reduces the expenditure-to-GDP ratio as expected. A change in the debt-servicing costs has a significant positive impact. Columns $2-5$ show the results for the various political-economic models. They examine whether the information provided by the salience model of spending preferences introduced here, or other information on the complexion and fragmentation of government, can add explanatory power to the base model.

According to our first variant of a top-down budget process, parliament first votes on the size of the budget and subsequently on the allocation of total expenditure to budget items. Consequently, the legislator in parliament who holds the median position on the level-of-expenditure dimension determines the level and an upward (downward) change in the median position should show up as an increase (decrease) in total expenditure. Using manifesto data to determine the median legislator's preferred spending level, the results reported in column 2 suggest that there is empirical evidence to support the argument.

Also in accordance with the first hypothesis, the expected policy change in the veto player model has a positive impact on total government expenditure (column 3). That is to say, if all governmental parties, given their preferred spending level as stated in the party manifesto, can agree on a spending cut, expenditure is likely to decrease. Vice versa, if a higher spending level than in the previous year is preferred by all governmental parties, government expenditure is likely to increase. The $t$-statistics of both estimates are 


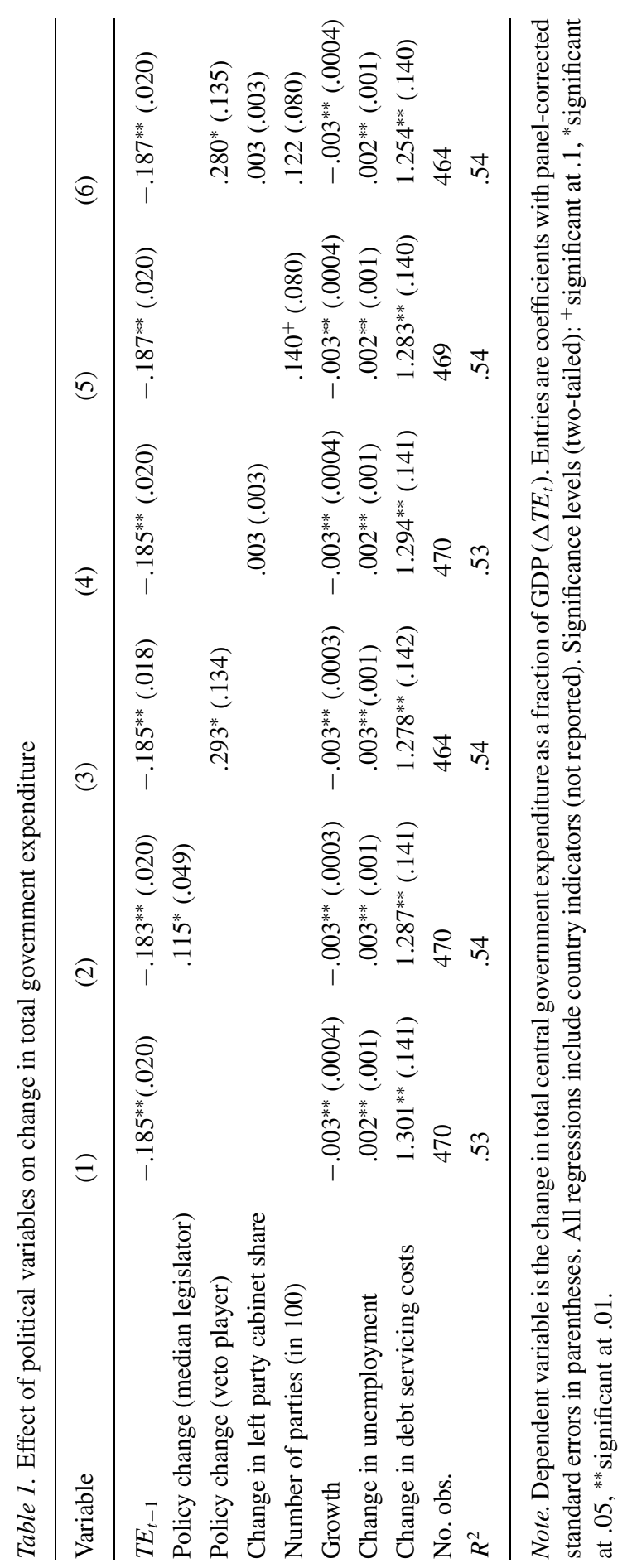


admittedly unimpressive, but given the sparse information on parties' fiscal preferences that party manifestos contain this is hardly astonishing.

The third model tests the parties-do-matter hypothesis in a more traditional way. According to the standard line of reasoning left-party dominated governments are expected to produce larger deficits and higher government spending as their constituencies are lower income groups generally favoring a large, active and market-regulating state. The model in column 4 uses a standard variable to indicate the partisan hue of government, namely the share of cabinet posts held by left parties (e.g., Hallerberg \& von Hagen, 1999). The results are not encouraging. The first difference of the variable has the expected sign but the effect is unsubstantial and far from any reasonable level of statistical significance. ${ }^{8}$

The fourth model, finally, seeks to test an alternative explanation that it is not the partisan hue of governments which determines their fiscal behavior, but rather the mere fact that governmental actors are concerned with providing benefits to their constituencies (or themselves), without taking into account the full tax implications of their spending. As a consequence of this common pool resource problem, so-called fragmented governments encompassing more parties are considered to exhibit higher expenditure and higher deficits (Roubini \& Sachs, 1989a). Using the number of governmental parties as a measure for fragmentation, column 5 suggests that there is some evidence for the argument, yet the effect is marginally significant. This is in line with recent findings of, for instance, Volkerink and de Haan (2001), arguing that there is a positive effect of the coalition size on expenditure whilst an effect on deficit is indiscernible. ${ }^{9}$

The explanations presented in the various models do not exclude one another. For theoretical reasons, the partisan identity of governments, for instance, may be relevant even when controlling for the preferences of the median voter (Aldrich, 1983). Similarly, in this context, partisan identity of governments may be relevant even when controlling for the (party manifesto based) spending preferences of governmental actors with respect to the size of the budget. To address this question I proceed in two steps. I first use Davidson and MacKinnon's (1981) $J$-tests to compare the various, nonnested linear models. Table 2 shows the $p$-levels of the pairwise tests. They indicate the $p$-level to reject the hypothesis that the row model encompasses the column model (cp. Franzese, 2002: 155). The message from the table is that the partisan model is most clearly dominated by all other models: the insignificant $p$-levels in column 4 together with the significant $p$-levels in row 4 indicate that party ideology doesn't add any information that is not covered by any of the three other models. The fragmentation model, however, does not contain information that is not already covered by the veto actor or the median legislator conception. Conversely, the insignificant results for their pairwise comparison suggest that the median and the veto player model of 
Table 2. Comparison of models of change in total expenditure (J-tests)

\begin{tabular}{lllll}
\hline Null/alternative & $(2)$ & $(3)$ & $(4)$ & $(5)$ \\
\hline (2) Median legislator & - & .579 & .184 & .135 \\
(3) Veto player & .153 & - & .243 & .221 \\
(4) Party identity & .006 & .014 & - & .104 \\
(5) Fragmentation & .009 & .023 & .200 & -
\end{tabular}

Note. Significant $p$-levels indicate that the column model contains information not covered by the row model.

budget politics both contain roughly the same information. Thus, at this stage there is no good argument in favor of or against one or the other.

Finally, in a combined model, I include all three types of information, spending preferences of governmental parties, their party identity and government fragmentation. The final column of Table 1 shows the results which confirm the evidence from the above $J$-tests. Only the veto player model significantly add independent information to the base model whereas the party ideology variable and the number of governmental parties prove to be insignificant.

\subsection{Impact of party preferences on expenditure mix}

Next, I examine the explanatory power of the salience model of budget politics for the expenditure mix for social security and economic affairs. Table 3 reports the results of an economic-condition base model, four politicaleconomic models adding one political variable at a time, and a combined model. Throughout the table, the dependent variable is the first difference of the ratio of social security expenditure to the aggregate expenditure on social security and economic affairs. All statistical models include the full set of country indicators. As the lagged level, but not the lagged difference, of the dependent variable proves significant in the base and all subsequent models, the level in the ratio of social security spending in the previous year is included $\left(S E_{t-1}\right)$.

Economic theory is ambiguous towards standard economic variables and indeed, most of the above variables do not significantly add information to the country-year null model (column 1). Growth impetus may decrease total expenditure (as a fraction of GDP) but does not favor social at the expense of economic affairs expenditure. One might expect that a rise in unemployment is likely to increase social security and welfare expenditure but the effect may be counterbalanced by equivalent increases in expenditure on economic affairs. In the base model the effect is positive but insignificant. The base model also contains the change in and lagged level of the pension-age share of the 


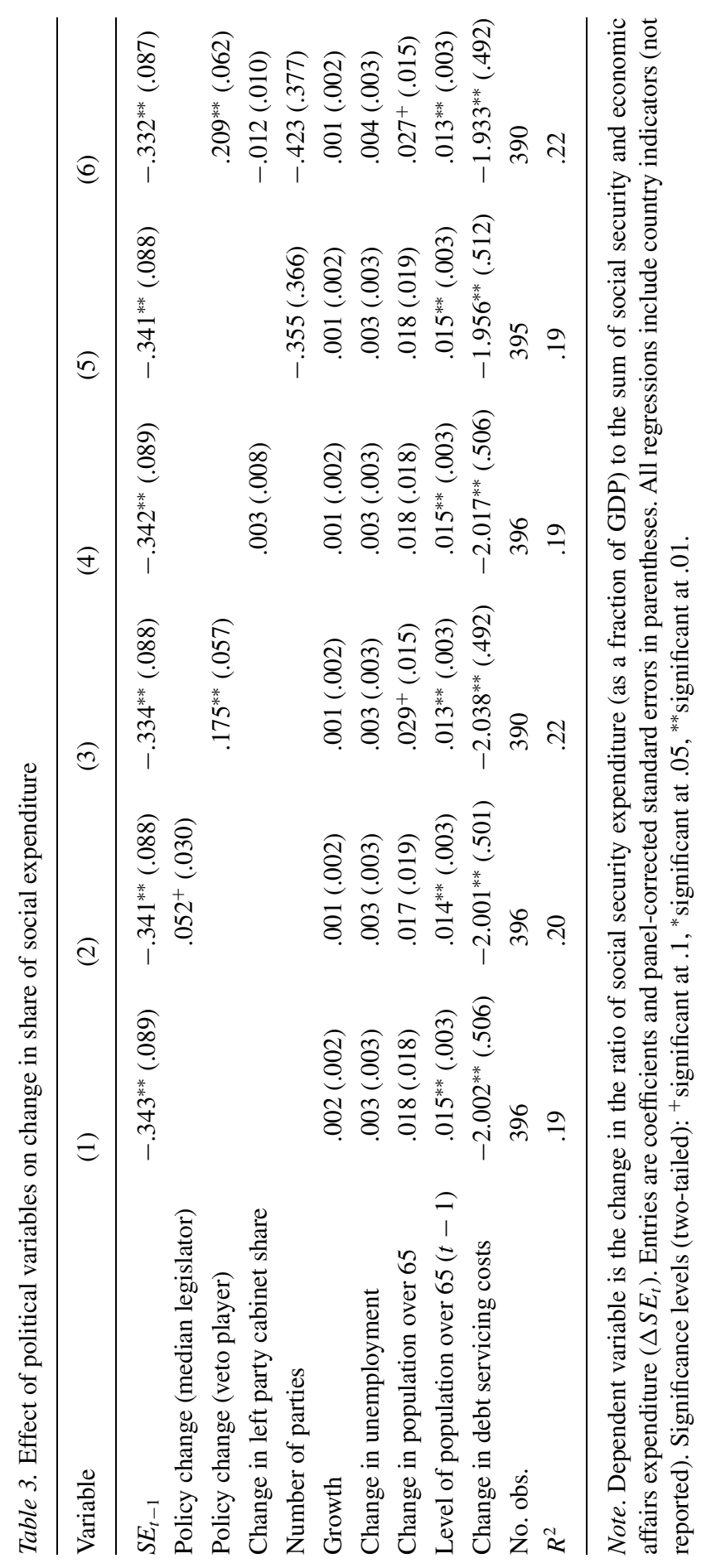


population as this variable is most likely to have a direct adjustment effect on social security spending but not economic affairs expenditure. The coefficients are positive but only the coefficient for the lagged level of the pension-share of the population is significant. In sum, this very simple economic-conditions base model has not much to tell us about the distribution of government expenditure to the budget categories of social security and economic affairs.

I now turn to the various political-economic models. It appears that the potential for policy change towards either social security or economic affairs spending affects the distribution of expenditure to the two budget categories (columns 2 and 3). A high potential for more social security spending does indeed result in higher expenditure for this area and vice versa. In the veto player model, a policy change of .5 (e.g., from a one party government putting $25 \%$ emphasis on social welfare and $75 \%$ on economic policy statements in its manifesto, to a one party government with a $75 \%$ to $25 \%$ salience ratio) implies a $.175 \times .5=.09$ increase in the social security expenditure share (column 3). This effect is both significant and substantial. A change in the position of the median legislator has a likewise positive impact but the effect is smaller $(.052 \times .5=.03)$ and at a lower $p$-level of significance (column 2$)$. Most interestingly, I am unable to discern a similar relationship for the partisan identity model. According to column 4, left governments may be characterized by higher social expenditure ratios but, again, the effect is infinitely small at an insignificant level. Finally, as expected, the fragmentation model tells us very little about the distribution of resources to the two spending categories.

Table 4 presents results from $J$-tests that compare each of the models against every other. The basic result is that the two preference-based models contain important information not captured by party identity model (nor the fragmentation model). Most notably, rejecting any of the other models in favor of the veto player model has diminishing small error probabilities. Finally, all three types of information, spending preferences, party identity and fragmentation, are included in a combined model. The final column of Table 3 presents the results which confirm the evidence from the above $J$-tests.

Table 4. Comparison of models of change in share of social expenditure ( $J$-tests)

\begin{tabular}{lllll}
\hline Null/alternative & $(2)$ & $(3)$ & $(4)$ & $(5)$ \\
\hline (2) Median legislator & - & .002 & .923 & .267 \\
(3) Veto player & .916 & - & .225 & .310 \\
(4) Party identity & .091 & .002 & - & .354 \\
(5) Fragmentation & .068 & .001 & .815 & - \\
\hline
\end{tabular}

Note. Significant $p$-levels indicate that the column model contains information not covered by the row model. 
Only the veto player model significantly adds valuable information to the base model whereas both the party ideology variable and the degree of governmental fragmentation turn out to be insignificant.

\section{Conclusions}

The main purpose of this paper has been to go beyond the existing notions of the effect of party politics on fiscal outcomes. Previous studies have largely focused on ideological differences or the party identity as expressed in the nominal label of parties. The contention often explored is that left and right-wing parties differ in their public policies and fiscal priorities; more specifically, left-party dominated governments are expected to spend more and run larger deficits. On the empirical side, findings have been encouraging but sometimes mixed; on the theoretical level, the partisan politics approach has come under attack by scholars pointing to the increasing role of international financial integration that leads to the expectation that distinct partisan differences in public policy are diminishing or even have been eliminated.

In this paper, I emphasize the distinction between the ideological identity of governmental actors and their programmatic policy and spending preferences. The question is whether "parties do matter" because of actual differences in their substantial preferences rather than the supposed differences which are derived from their ideological identity. To explore this question, the first section develops a model of budget politics that is based on the spending preferences of policymakers.

The empirical investigation reveals that the distinction between two aspects of partisan politics, the ideological identity of actors and their programmatic preferences is worthwhile. Above all, there is evidence for the presented model. It is not the left or right ideology of parties that has a significant effect on the expenditure level and mix but the programmatic preferences of governmental actors as stated in their electoral manifestos. The effect is considerable in size and proves statistically significant, particularly for the distribution of expenditure to the two budget categories considered in the empirical analysis.

Three further findings are noteworthy. The first refers to the institutional foundations of budgetary politics or how spending decisions are made. The empirical findings are in line with both the median legislator and the veto player perspective but, recalling the results in Table 4, favor the veto player model of governmental policymaking. Second, while I find evidence for the argument that government fragmentation or fractionalization, here in terms of the number of coalition parties, has a positive effect on the size of expenditure, fragmentation is irrelevant to the distribution of resources. This is perfectly consistent with the collective action literature arguing that the more dispersed the decision making authority is, the higher government spending is likely to be. Third, the $J$-test comparison of models of change in total expenditure 
provides a comparative test of the collective action approach (e.g., Kontopoulus \& Perotti, 1999) and policy inertia or delayed stabilization theories (e.g., Alesina \& Drazen, 1991; Tsebelis, 2002) to public policies and finance. The findings suggest that the empirical data do not reject that the policy inertia conception encompasses the collective action conception but they reject the converse.

\section{Appendix}

Proof of Proposition 3: For ease of exposition I focus on two spending activities $x_{1}$ and $x_{2}$ so that $B=x_{1}+x_{2}$ is the total expenditure and $k=x_{2} /\left(x_{1}+x_{2}\right)$ is then the expenditure mix. Let $B_{i}(k)$ and $k_{i}(B)$ represent actor $i$ 's most preferred total expenditure conditional on an expenditure mix $k$ and the most preferred expenditure mix conditional on a given total expenditure $B$, respectively. We have to show that $B_{i}(k)$ and $k_{i}(B)$ are not conditional on $k$ and $B$, or $B_{i}(k)=\hat{x}_{i}^{s}$ and $k_{i}(B)=\hat{x}_{i 2} /\left(\hat{x}_{i 1}+\hat{x}_{i 2}\right)$.

Given an expenditure mix $k$, actor $i$ 's most preferred total budget is at a point $z=\left(z_{1}, z_{2}\right)$ where the gradient of $u_{i}$ is perpendicular to the line through the origin with slope $k /(1-k)$ (Figure 1). In matrix notation, for some $l$ :

$$
\nabla u_{i}(z)=l\left(\begin{array}{c}
k /(1-k) \\
-1
\end{array}\right)
$$

In addition, from the definition of $k$ :

$$
z_{2}=\frac{k}{1-k} z_{1}
$$

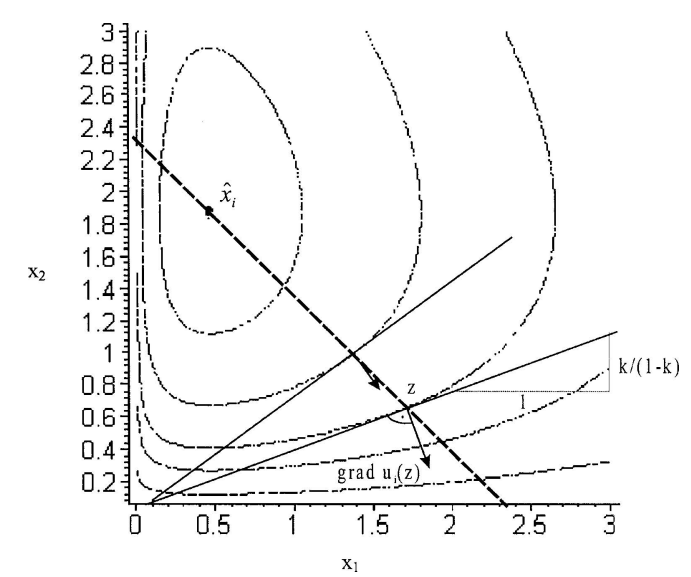

Figure 1. Spending preferences are separable across $B$ and $k$. 


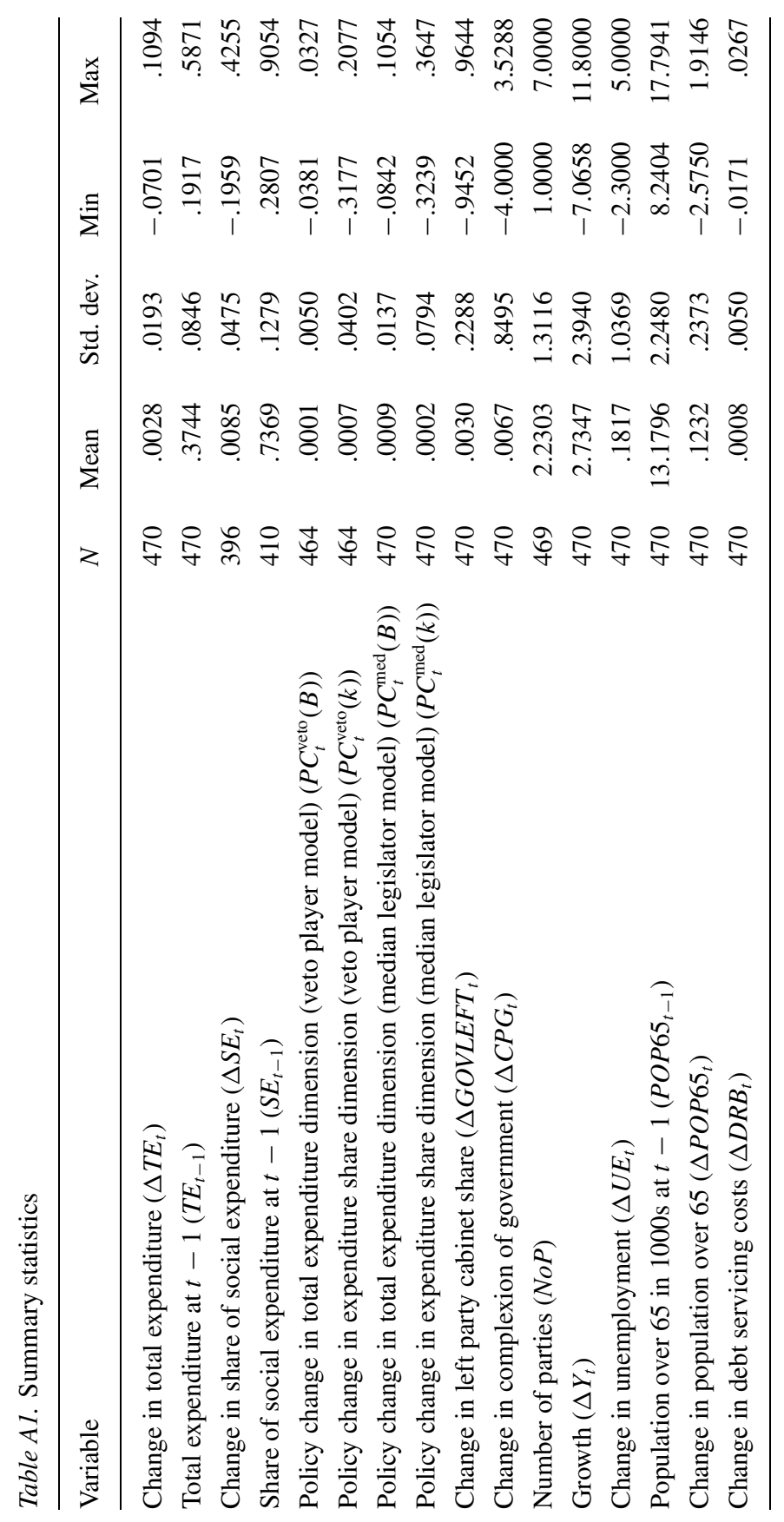


This yields three equations

$$
\begin{aligned}
& \left(1-\lambda_{i}\right) \alpha_{i 1} / z_{1}-\lambda_{i} m_{i}=l k /(1-k) \\
& \left(1-\lambda_{i}\right) \alpha_{i 2} / z_{2}-\lambda_{i} m_{i}=-l \\
& z_{2}=k z_{1} /(k-l)
\end{aligned}
$$

Solving for $z_{1}$ and $z_{2}$ yields

$$
z_{1}=\frac{\left(1-\lambda_{i}\right)(1+k)}{\lambda_{i} m_{i}} \quad \text { and } \quad z_{2}=\frac{\left(1-\lambda_{i}\right) k}{\lambda_{i} m_{i}}
$$

and so

$$
B_{i}(k)=z_{1}+z_{2}=\frac{1-\lambda_{i}}{\lambda_{i} m_{i}}=\hat{x}_{i}^{s}
$$

As to $k_{i}(B)$, the most preferred expenditure mix given a fixed $B$ is the one at which the gradient of $u_{i}$ is perpendicular to the budget simplex with slope -1 . Solving the equations

$$
\nabla u_{i}(z)=l\left(\begin{array}{l}
1 \\
1
\end{array}\right) \quad \text { and } \quad z_{1}+z_{2}=B
$$

for $z_{1}$ and $z_{2}$ yields $k_{i}(B)=z_{2} /\left(z_{1}+z_{2}\right)=\hat{x}_{i 2} /\left(\hat{x}_{i 1}+\hat{x}_{i 2}\right)$.

\section{Notes}

1. Previous versions of the paper were presented at the 99th Annual Meeting of the APSA, August 28-31, 2003, Philadelphia, the 2nd ECPR Conference, September 18-21, 2003, Marburg and at seminars at Trinity College Dublin, and the Universities of Mannheim and Zürich. Grant support is gratefully acknowledged from the Deutsche Forschungsgemeinschaft (BR1851/3-1). I also thank Patrick Bernhagen, William Clark, Robert Franzese, and Mark Jones for valuable comments.

2. Klingemann, Hofferbert, and Budge (1994) also focus on party preferences and analyze government expenditure for each of several policy areas. They find that to some extent, budgetary priorities can be traced back to differences in party manifestos but both their theoretical and statistical approach is severely criticized (King \& Laver, 1993; Thome, 1999; see, however, McDonald, Budge, \& Hofferbert, 1999 for a more sympathetic treatment). Tsebelis and Chang (2004) argue that changes in the policy preferences of governmental actors that constitute veto players for policy change induce changes in the composition of budgets or expenditure pattern. But this argument is based on "policy" rather than "spending" preferences and therefore offers no insight in the direction of change.

3. Political actors may differ with respect to $m_{i}$ : individual legislators are likely to have a smaller constituency than parties (as unitary actors) so that pork barrel politics should be more common when individual legislators are more independent in their vote or when they are elected under majoritarian electoral systems (see, e.g., Hallerberg \& von Hagen, 1999). 
4. Social Security and Welfare (B6; 710): expenditure for sickness and disability; old age; survivors; family and children; unemployment; housing. Economic Affairs and Services (B9-B13; $704+705)$ : expenditure for general economic, commercial and labor affairs; agriculture, forestry, fishing and hunting; fuel and energy; mining, manufacturing, and construction; transport; communication; other industries; waste management; waste water management; pollution abatement; protection of biodiversity and landscape. Codes in brackets refer to the classification as used in the IMF's Government Financial Statistics and the Classification of Functions of Government, COFOG (United Nations, Classifications of Expenditure According to Purpose, New York 2000, Appendix 4).

5. Another technique is the revelation of preferences from observed voting behavior as employed in roll call vote analyses (Poole \& Rosenthal, 2001). The problem of how to measure ex ante preferences rather than behavior, also exists there.

6. For social security, these are (CMP code): social justice (per503), welfare state expansion (per504), multiculturalism positive (per607), labor groups positive (per701), agriculture and farmers (per703), underprivileged minority groups (per705), non-economic demographic groups (per706). For economic affairs: incentives (per402), market regulation (per403), economic planning (per404), economic goals (per408), Keynesian demand management (per409), productivity (per410), technology and infrastructure (per411), controlled economy (per412).

7. Kontopoulus and Perotti (1999) and Tsebelis and Chang (2004) use the inflation rate instead of change in debt serving costs but inflation turned out to be insignificant in all subsequent models. I also tested for the inclusion of the economic controls at their levels but additional variables generally proved insignificant. The only exception is POP65 in the model of spending allocation.

8. I have experimented with an alternative, seminal indicator of government ideology, the "complexion of government" (Woldendorp et al., 2000) but also found no evidence in favor of the hypothesis.

9. To be more specific, Volkerink and de Haan (2001) use the "effective" number of parties in government. They find a significant effect for the variable on expenditure even though including the number of spending ministers outperforms the former.

\section{References}

Aldrich, J. (1983). A Downsian spatial model with party activism. American Political Science Review, 77(4), 1974-1990.

Beck, N., \& Katz, J. N. (1995). What to do (and not to do) with time-series cross-section data. American Political Science Review, 89, 634-647.

Blais, A., Blake, D., \& Dion, S. (1993). Do parties make a difference? Parties and the size of government in liberal democracies. American Journal of Political Science, 37(1), 40-62.

Budge, I. (2001). Validating party policy placements. British Journal of Political Science, 31, 210-223.

Budge, I., Klingemann, H.-D., Volkens, A., Bara, J., \& Tannenbaum, E. (2001). Mapping policy preferences. Estimates for parties, electors, governments, 1945-1998. Oxford: Oxford University Press.

Budge, I., Robertson, D., \& Hearl, D. (1987). Ideology, strategy, and party change: Spatial analysis of post-war election programs in nineteen democracies. London: Cambridge University Press.

Castles, F., \& Mair, P. (1984). Left-right political scales: Some expert judgements. European Journal of Political Research, 12, 83-88. 
Coleman, J. S. (1990). Foundations of social theory. Cambridge, MA: Harvard University Press.

Comiskey, M. (1993). Electoral competition and the growth of public spending in 13 industrial democracies, 1950 to 1983. Comparative Political Studies, 26(3), 350-374.

Cusack, T. (1997). Partisan politics and public finance: Changes in public spending in the industrialized democracies, 1955-1989. Public Choice, 91, 375-395.

Davidson, R., \& MacKinnon, J. G. (1981). Several tests for model specification in the presence of alternative hypotheses. Econometrica, 49(3), 781-793.

Denzau, A. T., \& Mackay, R. (1981). Structure induced equilibrium and perfect foresight expectations. American Journal of Political Science, 25(4), 762-779.

Enelow, J. M., \& Hinich, M. J. (1984). The spatial theory of voting. Cambridge, UK: Cambridge University Press.

Franzese, R. J. (2002). Macroeconomic policies of developed democracies. Cambridge, UK: Cambridge University Press.

Garrett, G. (1998). Partisan politics in the global economy. New York: Cambridge University Press.

Garrett, G., \& Lange, P. (1991). Political responses to interdependence: What's 'Left' for the Left? International Organization, 45, 539-564.

Hallerberg, M., \& von Hagen, J. (1999). Electoral institutions, cabinet negotiations, and budget deficits in the European Union. In J. M. Poterba, \& J. von Hagen (Eds.), Fiscal institutions and fiscal performance (pp. 209-232). Chicago: University of Chicago Press.

Hibbs, D. A. (1977). Political parties and macroeconomic policy. American Political Science Review, 71, 1467-1497.

King, G., \& Laver, M. (1993). Party platforms, mandates, and government spending. American Political Science Review, 87, 744-747.

Klingemann, H.-D., Hofferbert, R. I., \& Budge, I. (1994). Parties, policies, and democracy. Boulder, CO: Westview.

Kontopoulos, Y., \& Perotti, R. (1999). Government fragmentation and fiscal policy outcomes: Evidence from OECD countries. In J. M. Poterba, \& J. von Hagen (Eds.), Fiscal institutions and fiscal performance (pp. 81-102). Chicago: University of Chicago Press.

Kraan, D.-J. (1996). Budgetary decisions: A public choice approach. Cambridge, UK: Cambridge University Press.

Laver, M. (2001). (Ed.). Estimating the policy positions of political actors. London: Routledge.

Laver, M., \& Budge, I. (1992). Party policy and government coalitions. New York: St. Martin's Press.

Laver, M., \& Garry, J. (2000). Estimating policy positions from political texts. American Journal of Political Science, 44(3), 619-634.

Laver, M., \& Hunt, W. B. (1992). Policy and party competition. New York: Routledge.

McDonald, M. D., Budge, I., \& Hofferbert, R. I. (1999). Party mandate theory and time series analysis: A theoretical and methodological response. Electoral Studies, 18, 587-596.

Müller, W. C., \& Strøm, K. (2000). Coalition governments in Western Europe. Oxford: Oxford University Press.

Niskanen, W. (1971). Bureaucracy and representative government. Chicago: Aldine Atherton.

Oatley, T. (1999). How constraining is capital mobility? The partisan hypothesis in an open economy. American Journal of Political Science, 43(4), 1003-1027.

Poole, K. T., \& Rosenthal, H. (2001). D-NOMINATE after 10 years: An update to Congress: A political-economic history of roll call voting. Legislative Studies Quarterly, 26, 5-29.

Rose, R. (1984). Do parties make a difference? (2nd ed.). Chatham, NJ: Chatham House.

Roubini, N., \& Sachs, J. D. (1989a). Government spending and budget deficits in the industrial countries. Economic Policy, 8, 99-132. 
Roubini, N., \& Sachs, J. D. (1989b). Political and economic determinants of budget deficits in the industrial democracies. European Economic Review, 33, 903-938.

Thome, H. (1999). Party mandate theory and time series analysis: A methodological comment. Electoral Studies, 18, 569-585.

Tsebelis, G. (2002). Veto players: How political institutions work. Princeton, NJ: Princeton University Press.

Tsebelis, G., \& Chang, E. (2004). Veto players and the structure of budgets in advanced industrialized countries. European Journal of Political Research, 43(3), 449-476.

Tufte, E. R. (1978). Political control of the economy. Princeton, NJ: Princeton University Press.

Volkerink, B., \& de Haan, J. (2001). Fragmented government effects on fiscal policy: New evidence. Public Choice, 109, 221-242.

von Beyme, K. (1985). Political parties in Western democracies. Aldershot, UK: Gower.

Woldendorp, J., Keman, H., \& Budge, I. (2000). Party government in 48 democracies (19451998). Dordrecht, The Netherlands: Kluwer. 